\title{
Sex and the city: Silens and Nymphs in Ancient Greek pottery ${ }^{1}$
}

\section{El sexo y la ciudad: Silenos y Ninfas en la cerámica griega}

\author{
Fátima DÍEZ PLATAS \\ Universidad de Santiago de Compostela \\ fatima.diez@usc.es
}

Recibido: 26/11/2013.

Aprobado: 01//12/2013.

\begin{abstract}
This paper deals with the images of Silens and Nymphs together, especially in erotic scenes on black-figure vases from the sixth century B. C., usually considered as a repeated stock images, belonging to the general imagery of the Dionysiac thiasos. A further analysis on a few archaic vases shows that the erotic relationship between Silens and Nymphs have several features in common with mythic pursuit or rape scenes, and could be iconographically read as an attempt of showing an inversion of the heroic erotic values, proposing a counterpart model of the kind of wild love, which takes place in the imaginary world outside of the limits of the polis.
\end{abstract}

Key Words: Nymphs, Silens, Satyrs, Peleus, Thetis, Atalante, Hippomenes, agon, sexuality.

Resumen: Las imágenes de los Silenos y las Ninfas, y, de manera especial, las que presentan su relación erótica en la cerámica del siglo VI a. C. suelen ser consideradas como un conjunto de escenas de stock, que forman parte de la imagen general del tíaso dionisiaco. Un análisis más detallado de algunos de los vasos más antiguos, lleva a la conclusión de que la relación de Silenos y Ninfas tiene puntos de independencia figurativa con respecto a la relación de ambos colectivos con Dioniso, y que está basada, de manera clara, en un erotismo que las imágenes de la cerámica, por medio de distintas referencias, proponen como un modelo de erotismo salvaje o desinhibidamente libre, que se relaciona en términos de inversión con escenas de amor mítico y que se concibe como un fenómeno que tiene lugar en un lugar imaginario fuera del mundo ordenado y esencialmente humano de la polis.

Palabras clave: Ninfas, Silenos, Sátiros, Tetis, Peleo, Atalanta, Hipómenes, agon, sexualidad.

Sumario: 1. Introduction. 2. Sylens and Nymphs and the image of desire. 3. Chase, harassment and kidnapping or the violence as a way of encounter. 4. Epilogue: sex in the world of Dionysus. Bibliography.

$$
* * * * *
$$

\section{Introduction}

"with them [the Nymphs] the Sileni and the sharp-eyed Slayer of Argus mate in the depths of pleasant caves Homeric Hymn to Aphrodite, 262-263

The creation and definition of the polis as designed and regulated framework of Greek man's life entails the creation and definition of the spaces that oppose it or complement it, as an exercise of reflection on human life and their relation to other

\footnotetext{
${ }^{1}$ A former version of this paper was published in Spanish in 2004: F. DÍEZ PLATAS, "Sexo fuera de la ciudad: sátiros y ninfas en la cerámica griega arcaica", SEMATA, 16, pp. 277-299.
} 
worlds that appear as an expression of the strange, the much discussed phenomenon of "alterity" or otherness. The natural world, real but foreign, difficult and mysterious, becomes the scenery of myths ${ }^{2}$, a space in which the boundaries between man's life and the actions of gods is built, a territory in which, as it happened in the previous mythical times, epiphanies and fearsome encounter with the deity or with the beings who dwell in it in an imaginary way can still take place, because they take part from both worlds and move in the fabulous fringe where they come into contact.

In the domain of the images, which is the main focus of attention of this contribution $^{3}$, the prodigious Dionysiac iconography is the one in charge of placing before the eyes of the Greek spectator a special figurative version of this liminal territory into which Dionysus, the god of alterity and inversion par excellence, with the power of his weapons - the wine and the possibility of uninhibited seduction linked to it - can drag the man to make him enter a new dimension. The images created for the symposium are, from the beginning, a summary of proposals to experiment with the possibilities of going out towards this dimension thanks to the effect of the gift of Dionysus ${ }^{4}$.Within the Dionysiac realm, the privileged actors in the staging of this "reality" are the Silens or Satyrs ${ }^{5}$ and the Nymphs, who, as "companions of Dionysus", make up a clear group which is usually called Bacchic or Dionysian thiasos ${ }^{7}$, a kind of entourage of the god who seems to personify the divine action, as some kind of "plural expression". Along with the Silens and the

\footnotetext{
${ }^{2}$ R. BUXTON, R., Imaginary Greece. The contexts of mythology, Cambridge, 1994.

${ }^{3}$ This contribution deals with the images on archaic Greek pottery, and as the only reference to the vases that will be mentioned in the text it will be used the abbreviation BAD (Beazley Archive Database) and the number of the vase, that refers to the records in the Oxford Beazley Archive, which is the most complete compendium of Greek ceramics nowadays and which includes Beazley's quotations, the CVA references and the all necessary bibliographical data for identifying the vases and having access to the information published.
}

${ }^{4}$ These proposals were developed and transformed throughout time from the beginning of the 6th century BC, when the production of black-figure ceramics begins. On the iconography of Dionysus and the symposium in Archaic Greece see my recent updating: F. DÍEZ PLATAS "Dioniso en la figuración arcaica" in A.BERNABÉ/A. I. JiMÉNEZ/M. SANTAMARIA (EDS.) Dioniso. Los orígenes (Textos e imágenes de Dioniso y lo dionisíaco en la Grecia Antigua), Liceus, Madrid, 2013, pp. 275-399.

${ }^{5}$ In an effective way, Silen is a synonym for Satyr, although the evidence in the sources is not very helpful. In a general sense, satyr becomes the most common term, as HEDREEN points out (G. HEDREEN, "Silens, Nymphs, and Maenads", Journal of Hellenic Studies, vol. 114, 1994, pp. 47-69), because of the relationship with the so-called "satirical drama", but, in the image, they are identified for the first time as Silens in the François krater (Florence 4209. BAD 300000), which I will refer to later on. For a mere question of unification I will use the term Silen throughout these pages, which confirms the image, since the visual evidence I will consider all belong to the archaic period and to the black-figure technique.

${ }^{6}$ T. H. CARPENTER, Dionysian Imagery in Archaic Greek Art: Its Developement in Black-figure Vase Painting, Oxford, 1986, pp. 76 and ff.

${ }^{7}$ On the use of the term in relationship with the Dionysiac iconography see DÍEZ PLATAS 2013: 365, n. 457.

${ }^{8}$ On the entourage of the god see DÍEZ PLATAS 2013: 363-375 with lit. 
Nymphs - and in a similar way - there is also a "Dionysiac atrezzo", made up of animal, vegetable and inanimate elements which become attributes of the image of Dionysus and which are created and act with the power of metaphor and metonymy. All the cited elements refer to wine or to the power of Dionysus, but it is clear that most of them come from the natural world, which takes us to the space outside the polis.

From the natural space come also the Silens and the Nymphs themselves, as presumed inhabitants of this "external world", since the Nymphs are the image and personification of nature itself, seen as an intermediate world between gods and men $^{9}$, and the Silens, as hybrids - just like centaurs but in different proportion-, are a point of contact between animals and men, becoming another possibility of encounter with the world of "alterity" . And it is precisely nature, which supports the relationship between both groups, as sources remind us. The fragment of Hesiod (Fr. 10a M-W, 17-19), transmitted by Strabo (X, 3), and the verses of the Homeric Hymn to Aphrodite (vv. 262-263) are the first mentions in archaic texts of Satyrs or Silens, in which they are linked to Nymphs, sharing the same "ecological niche" - the natural space- due to the vital closeness that seems to emerge from their belonging to the same "species", coming from the gods, which involves them in the same genealogical line. This fosters, on the one hand, a family relationship, practically "fraternal" and, on the other hand, a kind of pairing off among equals, which turns them into real sexual partenaires ${ }^{11}$.

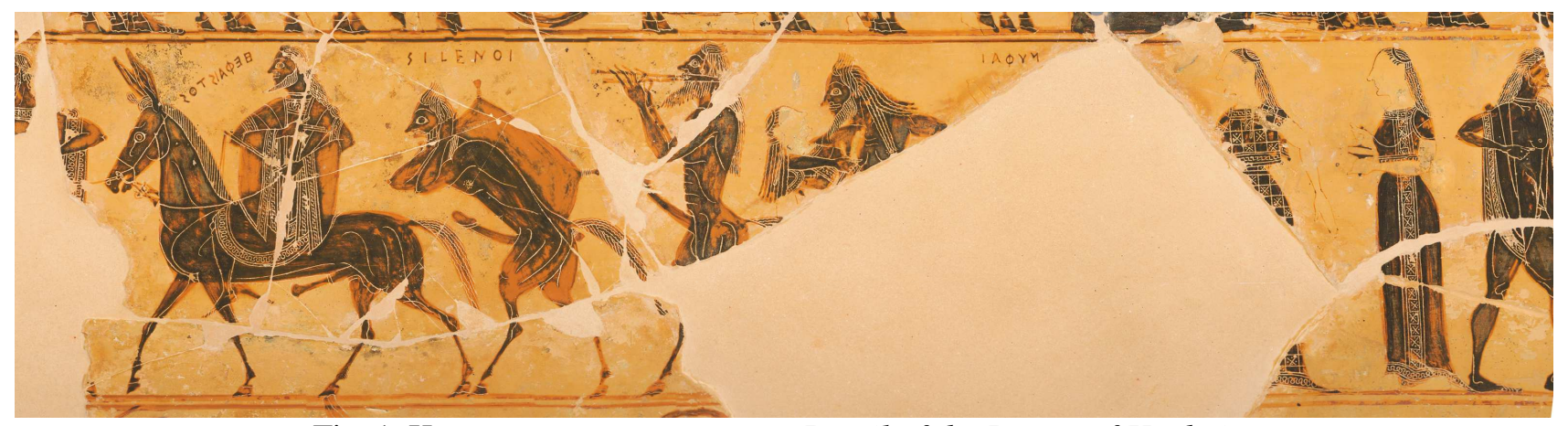

Fig. 1. KLEITIAS AND ERGOTIMOS, Detail of the Return of Hephaistos,

François crater, 565 BC. Florence, Museo Archeologico, 4209.

(Photo: courtesy of the Museum)

9 For Nymphs in archaic sources and their relationship with the natural world see the few references in J. LARSON, Greek Nymphs. Myth, Cult, Lore, Oxford University Press, 2001 and the second part of J. C. BERMEJO BARRERA- F. DíEZ PLATAS, Lecturas del mito griego, Akal, Madrid, 2002.

${ }^{10}$ On the question of alterity related to Dionysus and the Silens as members of a "mythical society" and inhabitants of the wild world see F. LISSARRAGUE, "On the Wildness of Satyrs", in T. H. CARPenter AND Chr. A. FARAONe (eds.), Mask of Dionysos, Cornell University Press, New York, 1993, 207-220. On their iconography see C. BERARD -CH. BRON, "Satiric Revels" in C. BERARD ET AL. (eds.), A City of Images. Iconography and Society in Ancient Greece, Princeton, New Jersey, 1989, p. 131-150, and, especially G. HEDREEN, Silens in Attic Blackfigure Vase-painting: Myth and Performance, Ann Arbor, The University of Michigan Press, 1992.

${ }^{11}$ On this relationship see BERMEJO BARRERA-DÍEZ PLATAS 2002: 249-255. 
The information from the textual sources about their relationship is visually confirmed when they appear on the so-called François Vase, the famous blackfigure crater painted by Kleitias around the $570 \mathrm{BC}^{12}$. The representation of Silens -characterized by a mixture of human and equine elements- and the Nymphs together ${ }^{13}$, accompanying Dionysus and Hephaestus on their return journey to the Olympus, and identified by their names engraved next to them $-\Sigma I \Lambda E N O I, N Y \Phi A I$ (Fig. 1) - is the confirmation of the image of Silens -whose appearance is not described in archaic sources-, in the ascertainment of the relationship between both groups -which is reinforced in the image of the third Silen of the procession who carries the first Nymph in his arms- and also in the "constitution act" of the circle of companions of the god, as it is the first image that shows them accompanying Dionysus. In this sort of constitution of the god, they are represented in such way as to become significant elements in the description of "Dionysian reality" and in the narration of the episode of The Return of Hephaestus to the Olympus, with the information he wants to convey, following the ancient Greek way of narrating with images in an exemplary way.

Thus, they are clearly depicted as groups and are marked not only by the collective names in plural, but also by the fact that they are three: the representation of the plural versus the unit and the couple. And each one of the members of the group of Silens -who, in their position and attributes, show that priority in the composition of the Dionysiac circle and in the relationship with the god and with wine, central element around which the whole mythical episode revolves ${ }^{14}$ - is carrying or holding one of the attributes that indicate or refer to the basic elements of the episode and the victory he celebrates. The first one is carrying a wineskin with the valuable element, the second one is playing music, and the third one is carrying a Nymph in his arms. Wine, music and sex are elements of the world of the symposium, owing to Dionysus or used to honour the god, and the Silens, helped -at least in the last aspect- by the Nymphs, are also in charge of "personifying" them in the visual memory this type of scenes involve.

On the other hand, the images that represent the Silens and the Nymphs, together and separately, in the company of Dionysus, are basically presented as a visual construction and the only testimony of a relationship that in principle archaic textual sources do not certify ${ }^{15}$. According to Isler-Kerenyi, the process of formation of these complex images, which include the presence of all the above

\footnotetext{
${ }^{12}$ BAD 300000. On the scene in the crater see DÍEZ PLATAS 2013: 364-366.

${ }^{13}$ On the specific question of the presence of Nymphs and Silens see F. DÍEZ PLATAS, "Las representaciones de las Ninfas en la cerámica griega arcaica y algunas consideraciones iconográficas", GALLAECIA, 17, 1998, p. 303-343, C. ISLER-KERENYI, Dionysos nella Grecia arcaica. Il contributo delle immagini, Istituti editoriali e poligrafici internazionali, Pisa-Roma, 2001, p. 87 and f., and DÍEZ PLATAS 2013: 367-370.

14 For the discussion on the incorporation of the Silens at the service of Dionysus and the Silens' introduction of the Nymphs in the thiasos see HEDREEN 1992; against this view ISLERKERENYI 2001.

${ }^{15}$ We can hardly refer to Nymphs as the god's nursemaids, as they appear in the Homeric hymn in honour of Dionysus (XXVI), and perhaps in the reference of Book VI of the Iliad (130-134), in the episode of Lycurgus: cf. see of J. C. BERMEJO BARRERA- F. DÍEZ PLATAS, Lecturas del mito griego, Akal, Madrid, 2002, pp. 209-231).
} 
mentioned elements, consists of the evolution of the image of the members of the komos, padded dancers who show the effect of wine on them in their movements and in the erotic situations which often follow the dances. Always according to Isler-Kerenyi, "becoming a satyr" is the process that these components of the Dionysian entourage follow and, as a result, the hybrid being appears in the figuration to personify the transgressing image of the follower of Dionysus. The Silen or Satyr, in his shaping and identity, lives and personifies the imaginary of transgression itself and facilitates the exercise of the inversion of the human image, especially because of his relationship with animality and with the wild world ${ }^{16}$.

But along with the Silens and their special image, we find the Nymphs, their natural companions, with whom they form an iconographically asymmetrical couple: hybrid nature versus completely anthropomorphical appearance. While Silens represent the projection of man's animality, which Greek images extensively explore $^{17}$, Nymphs, with their completely anthropomorphical and paradigmatically young and beautiful appearance, personify the role of femininity in their essential relationship with nature and with erotic power ${ }^{18}$. Both of them involve the result of reflection upon the nature of sexes and, precisely, in sex and eroticism is where the key to their relationship is found. The exacerbated and excessive sexuality of the Silens is visually manifest in the size of their genital organs, in their state of constant arousal and their lecherous behaviour when alone and in company ${ }^{19}$; the Nymphs' condition is disguised in the game of rejection and acceptance which can be seen in many of the images, although some moments in which they appear as intentionally provocative in their attitude or nudity, suggest the erotic personality they have ${ }^{20}$.

\footnotetext{
${ }^{16}$ ISLER-KERENYI 2001: 66-67.
}

${ }^{17}$ F. LISSARRAGUE in his chapter about the savagery of the Silens (LISSARRAGUE 1993) offers an highly interesting explanation of the animality of these beings and the role that this hybrid creation plays on Greek culture as a model of inversion of human rules, and, thus, as a kind of negative affirmation of human nature. In addition, C. CALAME also reflects on the Athenian's reflection upon the limits between men and animals in relation to eroticism and Dionysus: C. CALAME, Eros en la Antigua Grecia, Akal, Madrid, 2002, pp. 135-139 (Spanish version of L'Éros dans la Grèce Antique, Laterza, Roma-Bari, 1992).

${ }^{18}$ On this questions cf. F. DÍEZ PLATAS, "Los epítetos del amor y el deseo en la épica griega arcaica" in Actas del X Congreso Español de Estudios Clásicos, vol. I, Madrid, 2000, p. 385-390, "Naturaleza y femineidad: los epítetos de las Ninfas en la épica griega arcaica", Cuadernos de filología clásica: estudios griegos e indoeuropeos, 10, 2000, pp. 19-38, and the second part of J. C. BERMEJO BARRERA- F. DÍEZ PLATAS, Lecturas del mito griego, Akal, Madrid, 2002, chapters XIV and XV.

19 LiSSARRAGUE emphasizes the fact that Silens cannot control their desire, pointing out that they are "voyeurs and violators (...). More often than not they are reduced to solitary practices" (LISSARRAGUE 1993: 214).

${ }^{20}$ A type of personality which is strengthened in the image with a series of attributes it acquires through time- snakes, ivy, etc..- which have nothing to do with actual menadism, especially in the scenes that show Silens and Nymphs together. These elements have been considered, however, as a proof of another kind of divine possession. A germ of this idea can be found in HEDREEN 1994 and in DÍEZ PLATAS 2013: 367-368. 
The images in the Attic black-figure pottery seem to insist on this relationship of a sexual kind, confirming the status of Silens and Nymphs as a partners, who, although it is evident that they submerge in a natural way into the Dionysian scenes as elements of the world of the god, they also do get together quite often without the company or protection of the god, which is very significant ${ }^{21}$. Thus, they appear alone in numerous scenes that we tend to identify as unmistakably Dionysiac due to the other elements of the "atrezzo", turning into a kind of abbreviation or example of major scenes with a different type of development; or, using iconographical terms, they rather become Dionysiac motifs, which automatically refer to the image of the god and his "reality". But, in fact, the independent relationship they seem to have - and which, as we have seen, is confirmed by the textual sources-, in the field of the image seems to be previous to their first representation with Dionysus, although perhaps this is nothing more than a conservation issue. On the other hand, they really seem to be quite independent as characters, what, from my point of view, allows them to easily split off the complex scenes with the god, to appear -in groups or in isolated couples- as devoted to the true basis of their relationship: the excessive passion for sexual contact, which the Silens show and the Nymphs favour and accept.

\section{Silens and Nymphs and the image of desire}

The existence of three Attic vases dated before the François Vase with couples of Silens and Nymphs in settings that do not necessarily suggest the presence of Dionysus, has been used for some authors as a basis to defend the figurative existence of Silens and Nymphs outside the god's sphere of action, as independent beings who in a given moment get in contact with him and become his followers and helpers in certain circumstances ${ }^{22}$.

21 There are some black-figure vases listed in the Beazley Archive which show scenes with Silens and Nymphs alone.

22 A relevant exposition of the existence of Silens as a group which is independent from Dionysus but relates to the god afterwards, can be found in CARPENTER's study about Dionysian iconography in black-figure pottery (CARPENTER 1986) and in G. HEDREEN's book about the Silens in the same period (HEDREEN 1992). CARPENTER's exposition in the above mentioned chapter "Companions of Dionysos" (pp. 77-97) is especially detailed in the commentary of the sources, although his discussion of the identity of the feminine elements of the circle of the god, that is, the discussion of the question of Nymphs or Maenads as the Silens' companions is not too conclusive and is not based on iconographical criteria. HEDREEN in his chapter: "The Silens of Naxos" (pp. 67-104) proposes a specific geographical link for the Silens who meet Dionysus on the island of Naxos and start to take part in the events which will take place there: the finding of Ariadne and the banquet to get Hephaestus drunk. On the other hand, C. ISLER-KERENYI (ISLER-KERENYI 2001: 82 and f.), does not think there is a possible independence between the Silens and Dionysus, and does not consider the autonomy of the members of the Dionysiac circle either, as her study mainly tries to explain the elements of Dionysian iconography, integrating them into a great programme of references, although she refers to the komasts' erotic behaviour, with the aggressive notes, which can also be seen on the first vases in which the Silens and Nymphs appear. 
In the three pieces dated approximately in the same period-a lekythos in Buffalo $(\mathrm{USA})^{23}$, a dinos from Athens ${ }^{24}$, and a small fragment of a dinos now in Istambul ${ }^{25}$ a single couple formed by a Silen and a Nymph in different attitudes is depicted compounding a scene probably with no trace of the presence of Dionysus or of the "Dionysiac atrezzo", which will appear in later examples.

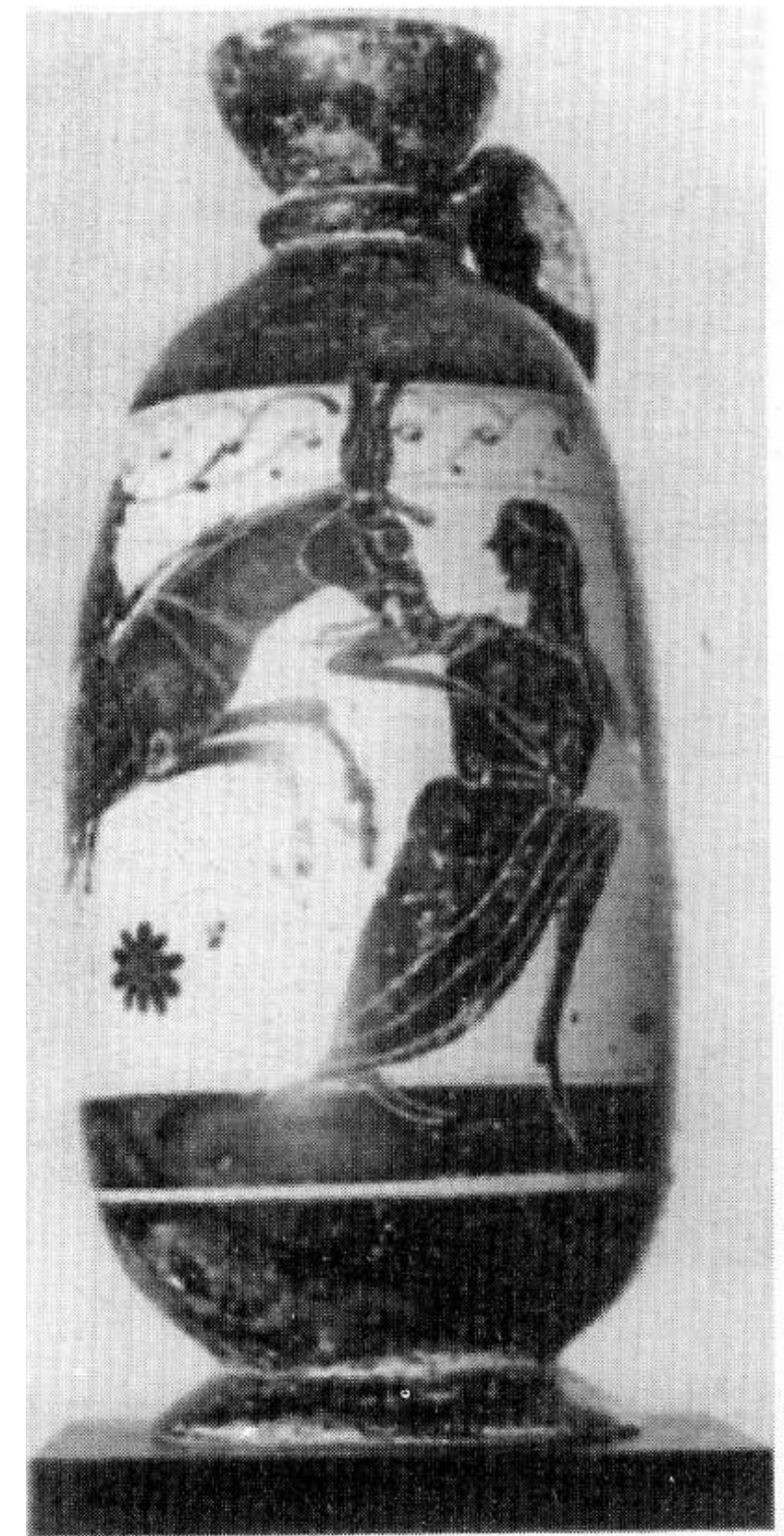

Fig. 2. Black-figure lekythos. Ca. 600-580 BC. Buffalo (NY), Albright-Knox Gallery G 600. ,

\footnotetext{
${ }^{23}$ Buffalo, Albright Gallery G 600 (BAD 300105). The vase has been dated between 600 and $580 \mathrm{BC}$ and atributted to the Gorgon Painter circle.

${ }^{24}$ Athens, Agora P334 (BAD 300278). The vase has been dated around 580 BC, and is connected with the group of the Dresden Lekanis.

${ }^{25}$ Istanbul 4514 (BAD 305096). The vase, dated around 580 BC, was found in Lyndos (Rhodes) and is attributed to the painter Sophilos.
} 
(Photo: ISLER-KERENYI 2001, fig. 36)

A couple formed by a Silen and a Nymph is the only decoration on the Buffalo lekythos (Fig. 2), which shows a unique scene ${ }^{26}$, in which a hairy and ithyphallic Silen rides galloping a mule, which is clearly biting the arm of a long-haired Nymph that wears a beautiful peplos and runs in front of the mount, flying and turning to look back.

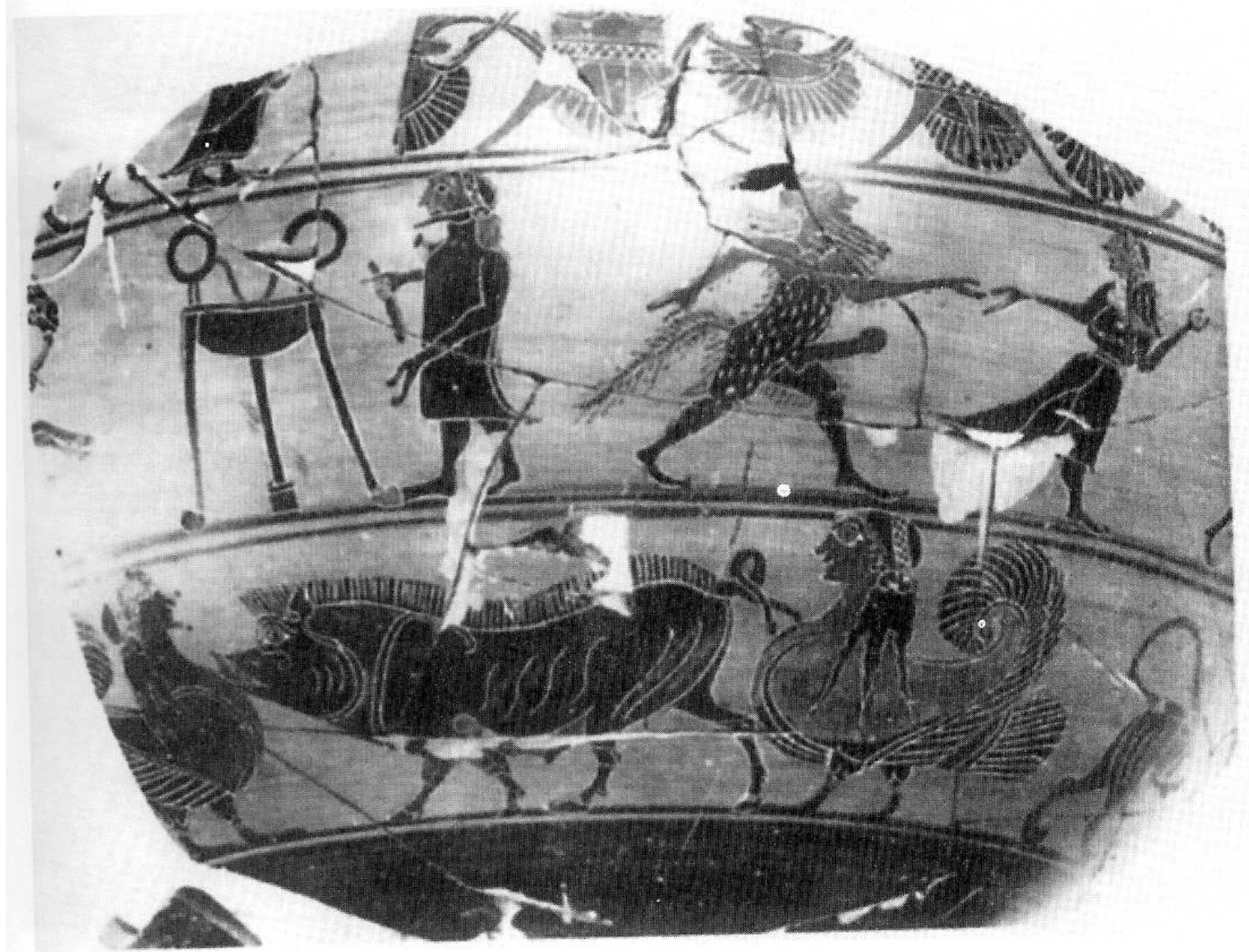

Fig. 3. Black-figure dinos, ca. 580 BC. Athens, Agora Museum P334.

(Photo: ISLER-KERENYI 2001, fig. 34)

The Agora dinos (Fig. 3), instead, contains several narrative scenes distributed on different bands. Between two of them -the hunting of the Calydon boar and the short representation of the funeral games in honour of Pelias- comes an odd couple of figures that seem to pay no attention to what is happening on each side of the vase. A bearded and hairy Silen with a horse's tail and an enormous erect phallus, but with human legs and hands, is running to the right, chasing a Nymph wearing a short dress, below the knee, and a ribbon tying her long hair. She turns to him and holds out her left hand as if wanting to touch the Silen's hand, while her

\footnotetext{
${ }^{26}$ According to M. BIEBER ("Two attic black-figured lekythoi in Buffalo" in AJA, 1944, 121131) this motif is unique in Greek art, although the presence of Nymphs, Silens and donkeys together can again be seen on the decoration of cups, in the 6th century BC.
} 
right hand is holding what several authors consider to be a stone that she is about to throw at $\operatorname{him}^{27}$.

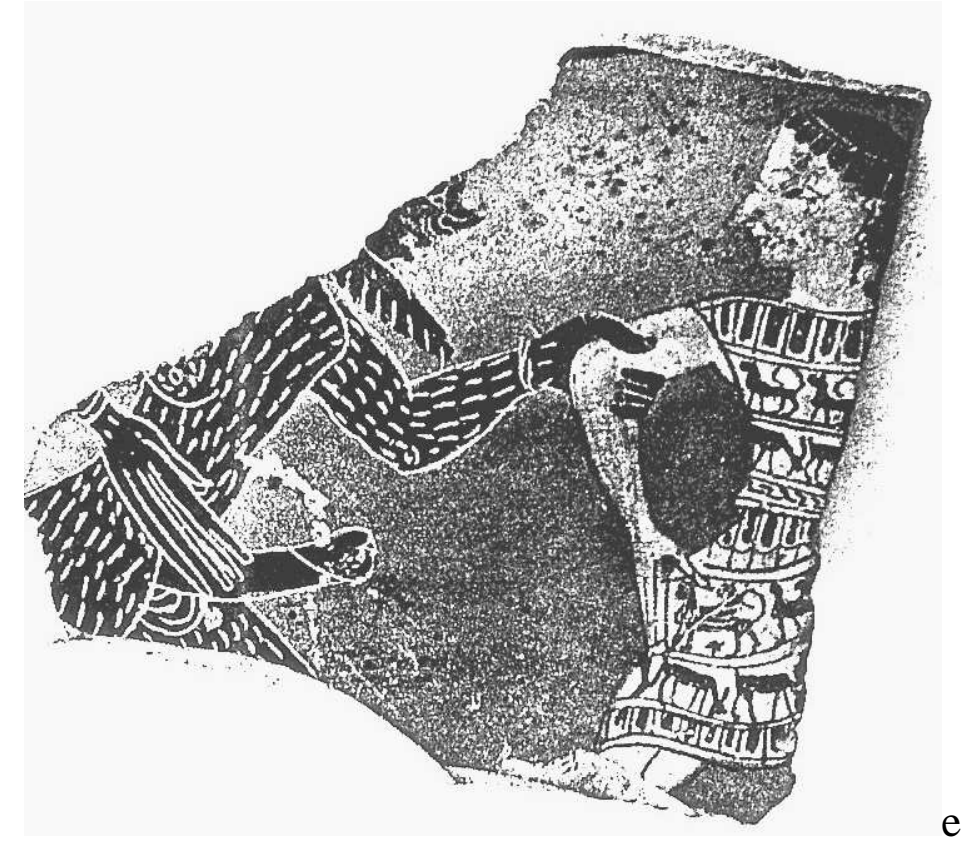

Fig. 4. Black-figure dinos (fragment), ca. 580 BC, Istambul, Istambul Archaeological Museum 4514. (Photo: MORAW 1998, lámina 1.2)

Finally, the only part preserved from the scene in the fragment of the vase attributed to Sophilos and conserved in Istanbul (Fig. 4), is also a part of the representation of a couple formed by a Silen and a Nymph: another hairy ithyphallic Silen takes a woman by her arm, and she turns to him with a calm attitude. It is easy to identify as a Nymph, the feminine figure with very white skin, contrasting with the Silen's darkness, dressed on a beautiful short chiton decorated with animal friezes and tongues, that wears earrings and a very nice hairdo, with waves and the customary taenia holding her hair ${ }^{28}$.

On one hand, the autonomy of the representation of Silens and Nymphs in the commented pieces seems evident, except, perhaps in the last case, in which the fragmentary state of the piece prevents us from knowing in what context the two figures were or if they were part of a larger scene; on the other, they seem to

27 R. S. Young ("A Black-Figured Deinos" in Hesperia, 4, 1935, p. 430-441), CARPENTER 1986: 81 n. 22 and 121) and S. MCNALLY ("The Maenad in Early Greek Art" in J. PERADOTTOJ. P. SUllivan (eds.), Women in the Ancient World. The Arethusa papers 11, SUNYP, Albany, 1978 , p. 113), on comenting the vase, refer to the Nymph's attitude as defenssive, proposing that she is trying to throw a stone at the Silen, as a response to the aggression that the scene may suggest, but McNally suggests -rightly from my point of view- that the other hand of the Nymph is inviting the silen and a doubt about her aggressive attitude is posed.

${ }^{28}$ HEDREEN's comment about the Silen's appearance and the fact that he seems to be wearing a costume and a mask on his face (HEDREEN 1992: $96 \mathrm{n} .70,126$ ) may also indicate that it may be part of a theatrical performance. This is the theory he maintains throughout his whole study: the representations of Silens can often be no more than representations of people dressed as Silens. And as regards this specific passage by Sophilos, in which only the upper part of the Silen is preserved, he draws the attention to the two lines that separate a hairy arm from a soft-skinned hand can be seen on his wrist. 
confirm, somehow, if not the previous existence of the groups and their incorporation into the Dionysiac world we have talked about, at least the hypothesis of the independence of the scenes as an iconographical motif, which is developed with certain meaningful autonomy, although it is linked afterwards -like other elements that appear with time - to the scenes in which the presence of the god is the central element.

What seems to be unquestionable is that the commented scenes are the visual proof of the clearly erotic relationship between Silens and Nymphs, becoming the first signs that the terms of the presence of Silens and Nymphs in figuration ${ }^{29}$ are erotic rather than merely Dionysiac, in the sense that they are the result of some kind of mythical "comensality", of the shared drunkenness or of the natural personification of happiness music causes and which leads to dance. Before appearing as dancing, the first Silens chase, attack, approach or manage to get the Nymphs, as those three commented scenes and also the couple of Silen and Nymph in the François vase show ${ }^{30}$.

As part of the Dionysiac world and image, Silens and Nymphs will also adjust their relationship, modifying their way of showing the eroticism they represent, using attributes to strengthen it without making it explicit, and combining it, in addition, with music and the enthusiasm that wine causes. Thus, Silens appear as elements related to the wine itself $^{31}$, and Nymphs show the feminine side which closely relates them to water, to the point of playing the role of the liquid element helped by some attributes - which is linked to wine and to Dionysus ${ }^{32}$.

29 This happens not only in pottery, but we would need to consider the representation of Silens and Nymphs alone in other different objects, such as coins or sculptural relieves: ISLERKERENYI 2001: 236 and F. DÍEZ PLATAS, Las Ninfas en la literatura y en el arte de la Grecia arcaica. Universidad Complutense de Madrid. Doctoral dissertation CD-ROM, 2002.

30 F. LISSARRAGUE (LISSARRAGUE 1993: 210) writes a lengthy commentary about the exacerbated eroticism we have talked about, emphasizing the idea that Silens rarely achieve their erotic purposes, an aspect which the scenes of some red figure vases highlight, but not the black figure ones. Once again, the question is probably no more than a visual narration problem; In the scenes representing the well-known episode of Thetis and Peleus, we know that the union is going to be consummated but we never see $i t$; it is obviously presumed but it is not more than an aspect of the collection of data containing the episode and which can be summarised in the scene of the kidnapping or the fight. The fact that we see more examples of struggles and erotic games than actual unions in the scenes of Silens and Nymphs together, does not mean that they do not take place, it only means that we do not see them, because the game is more important than the obvious outcome.

31 The Silens' relationship with wine is suggested not only by the scenes of grape harvest and drinking which begin to appear by mid 6th century BC (HEDREEN 1992), but also by the names inscribed on the vases (A. KOSSATZ-DEISSMAN, "Satyr- und Mänadennamen auf Vasenbildern des Getty-Museums und der Sammlung Cahn (Basel), mit Addenda zu Charlotte Fränkel Satyrund Bakchennamen auf Vasenbildern (Halle, 1912)", in Occasional Papers on Antiquities, 7, Malibu, 1991), which refer to Dionysus' gift or are even identified with him. Besides, the relationship that Silens establish with vases and containers is proverbial, as they even personify drunkenness itself (J-L. DURAND-F. FRONTISI-DUCROUX-F. LISSARRAGUE, "Wine: human and divine" in C. BERARD ET AL. (eds.), A City of Images. Iconography and Society in Ancient Greece, Princeton, New Jersey, 1989, p. 121-129).

${ }^{32}$ On water, wine and Nymphs see F. DíEZ PLATAS, "Imaginando el agua: Reflexiones acerca del significado iconográfico de la serpiente en algunas escenas de la cerámica griega arcaica", in P. 
Due to its amplitude, the analysis of this specific group of images in relation to the eroticism of Silens and Nymphs in black figure pottery could undoubtedly become an iconographical theme in itself that has seldom been tackled in a specific way; nevertheless, the theme deserves a more detailed study, which cannot be carried out thoroughly in the limited framework of these pages either ${ }^{33}$. I would like, however, to point out that it would be necessary to analyse these images, especially to clarify two generally accepted interpretations: the first one, the "transformation of the Nymphs into Maenads", which is based on the changing of clothing and attributes that the Silens' partners begin to experience ${ }^{34}$, which leads to Heinrichs's statement that "the maenad is so because of her appearance and not her company" ${ }^{35}$; the second one, the interpretation of the changing attitudes of Nymphs in their erotic relationship with Silens on the basis of personality changes or substitutions in the Dionysiac circle. In my opinion, both problems must be basically regarded as a visual answer to the problems that poses the image itself. From this point of view, it can be argued that the change of "clothing or attributes" of the feminine figures who interact with the Silens along the production of blackfigure vases does not affect the identity of Nymphs, or to the nature of their relationship with Silens, but it actually confirms both things, and, similarly, the Nymphs' change of attitude regarding the Silens' advance could rather be seen as the product of different visual y narrative strategies typical of the different moments of ancient art and of the development of narrative capacity, denotative and connotative of the image ${ }^{36}$.

In general, the display of eroticism in the scenes along the 6th century $\mathrm{BC}$, can be seen in different moments and is carried out in different ways, as if there was a

LÓPEZ BARJA -S. REBOREDA MORILlo (eds.), Fronteras e identidad en el mundo griego antiguo, Universidad de Santiago/Universidad de Vigo, Santiago de Compostela, 2001, p. 281301.

${ }^{33}$ The special and independent relationship between Silens and Nymphs in pottery is also dealt with in A. SCHÖNE's thesis on the Dionysiac circle (A. SCHÖNE, Der Thiasos: Eine ikonographische Untersuchung über das Gefolge des Dionysos in der attischen Vasenmalerei des 6. und 5. Jhs. v. Chr., Goteburgo, 1987). Few years before, S. MCNALlY (MCNALlY 1978) had analysed the Nymphs' behaviour and relationship with Silens in the ancient Greek art of the first period closely, paying special attention to the images in pottery and focusing on the evident change of attitude and appareance of Nymphs in red-figure pottery. The topic has been addresses afterwards in HEDREEN 1994, and in a German dissertation on Maenads: S. MORAW, Die Mänade in der attischen Vasenmalerei des 6. und 5. Jahrhunderts v. Chr. Receptionsästhetische Analyse eines antiken Weiblichkeitsentwurfs, Verlag Philipp von Zabern, Mainz, 1998.

${ }^{34}$ M. W. EDWARDS, "Representations of Maenads on Archaic Red-figured Vases", JHS, LXXX, 1960, p. $79-87$

35 A. HENRICHS, "Myth Visualized: Dionysos and His Circle in Sixth-Century Attic VasePainting", in Papers on the Amasis Painter and His World, Malibu, 1987, p. 92-124.

36 On these question see HEDREEN 1994, and DÍEZ PLATAS 2002. Neither the work of VILLANUEVA-PUIG ("Les representations des Menades dans la ceramique attique a figures rouges de la fin de l'archaisme", REA, 94, 1-2, 1992, p. 125-154) nor the study of S. MORAW (MORAW 1998.) draw any iconographical distinctions in the numerous and different images of Dionysus' feminine followers which are fundamental in order to be able to achieve a coherent interpretation. 
complete repertoire available to show the stages and details of a special sexual relationship, which takes place in an imaginary world in a double sense: in the mind and in the image. The relationship between Silens and Nymphs, even when they are part of larger scenes, reveals a complete repertoire of gestures, attitudes, actions, and even an "atrezzo", which I have already mentioned several times, which shows the stages and the figurative memory of the erotic relationship. From the ambushing, which figuratively turns Silens into "spies" of the Nymphs' intimacy, to the complete consummation of the relationship in all positions, the images of Silens and Nymphs offer a sampler of pursuits, fictitious escapes, different types of harassment, erotic games and dances, which serve as a codification of the ritual of rejection and acceptance.

\section{Chase, harassment and kidnapping or the violence as a way of encounter}

And among the whole collection of erotic samples, we should point out the controversial scenes that show the violence that Silens exert upon the Nymphs, who seem to be the victims that end up submitting to a situation, which they seemingly reject ${ }^{37}$. The paradoxes, which the image of these encounters seems to pose, have raised doubts when it comes to interpreting the scenes of pursuit or harassment that can be seen in the first moments, when they appear without the influence of the thiasos and of the possible phenomenon of codification. There are scenes that question the nature of the relationship between both parts, and have caused the well-known -and already mentioned - discussion about the Nymphs' identity in the world of Dionysus, exaggerating the couple's asymmetry ${ }^{38}$. The problem, as I have just indicated, comes from the very interpretation of the images and from the resulting assignment of meanings, by taking to other fields what it is basically a visual problem.

The oldest images of the relationship between Silens and Nymphs found on the three vases from the beginning of the sixth century BC, which we have already talked about, contain this type of scenes in which both the attack and the acceptance seem evident. The Agora dinos and the Sophilos fragment are good examples of this apparently contradictory behaviour. The Nymph that runs away from the Silen on the first vase (Fig. 3) is doing so while her torso is turning towards her pursuer, her face is looking at him and she's holding out her right hand towards his extended hand, while with her left hand she seems to be threatening him with what for some authors, is a stone; that is, she is putting into practice a defence which seems to turn into an attack. The Silen of the Sophilos vase (Fig. 4) holds the Nymph firmly with his hand, in a gesture which, if not violent, it is at least forceful; and she seems to be turning away from him while her face turns to look at her aggressor in an ostensible way, clearly establishing visual contact, which precisely indicates a key moment in

37 Although he does not discuss the subject thoroughly, CALAME's approach in the chapter "Pragmatics of erotic iconography" questions the sense of love violence and its expression in relation to the images of the gods and, especially, about the role of the Satyr's lust in the representation of love (CALAME 2002: 79-85).

${ }^{38}$ MCNALLY 1978. 
the erotic encounter: the mutual falling in love which is expressed and codified in the look ${ }^{39}$.

The mechanisms of figuration in the Ancient world show a series of specific characteristics which can be regarded as expression procedures that try to turn the image into a synthetic outline of data, disregarding the elements of time and space for clarity's sake, counting on the necessary help of the well-versed member of the audience, who can successfully decode the complete synoptical messages of the archaic image $e^{40}$. Thus, the archaic image which can - as it does- present the different phases of an episode as simultaneous and connected, like a twinned crystal, as we can see in examples such as the famous cup in Boston with the episode of Circe and Odysseus' companions or the different representations of the Polyphemus episode ${ }^{41}$, can also show the relationship between Silens and Nymphs condensed into a single scene whose main elements are the members of the couple, the signs of desire in the Silen's arousal, the erotic game of the previous resistance captured in the movements of pursuit and escape that the feet show -and which will obviously become steps of a more complex dance ${ }^{42}$ - and also the final acceptance as the outcome of the love tension, with rejection as incentive, and which is expressed through the holding out hands and the meeting gazes.

In other words, Archaic art does not only show Achilles' killing of Penthesilea, as we can see in the famous amphora by Exekias (Fig. 5) ${ }^{43}$, but the whole development of the love drama condensed in the look, the attack and the embrace which can be seen in the sole image of the couple's union. The same occurs in the scenes of Peleus' attempts to win Thetis, to mention just another example, which I regard as especially relevant when it comes to interpret the image of the relationship between Silens and Nymphs; in the Thetis and Peleus scenes we can see, equally condensed in the central couple and helped by the presence of signs or animal figures, the hero's attack, the Nereid's resistance, shown with her metamorphoses and even the successful attempt seen in the gesture of the head and in Peleus' strong embrace.

${ }^{39}$ On the look and its erotic value in iconography see F. FRONTISI-DUCROUX, "Eros, Desire and the Gaze" in N. B. KAMPEN (ed.), Sexuality in Ancient Art, Cambridge University Press, 1996, p. 81-100, although it mainly focuses on red figure pottery and the classical period.

40 On the narrative technique in the scenes of Archaic figuration and the so-called synoptical narration, see N. HimMELMAN, Erzählung und Figur in der archaischen Kunst, Wiesbaden, 1967, A. SNODGRASS ' chapter on archaic figuration "The first scenes with figures of Greek art" (A. SNODGRASS, An Archaeology of Greece, Barcelona, 1990, pp. 148-186), H. A. SHAPIRO, Myth into Art. Poet and Painter in Classical Greece, London, 1994, pages 7-10, and, above all, A. SNODgrass, Homer and the Artists. Text and Picture in Early Greek Art, Cambridge, 1998, where he explores the visual mechanisms of archaic figuration in a masterly way.

41 The famous cup at the Boston Museum (MFA 99.518; BAD 302569) and the different archaic vases -Argive, Laconian and Attic- which represent the Homeric episode in some scenes that "summarise", in a temporally and spatially impossible way, Polyphemus' cannibalism, the Cyclops' drunkenness, the blinding and the escape from the cave. For these vases and their analysis see SNODGRASS 1990 and 1998.

${ }^{42}$ F. DÍEZ PLATAS, "Dos caras de una cílica: sobre la iconografía de la copa de Fineo", GALLAECIA, 22, 2003, (87-102), pp. 93-95.

${ }^{43}$ London, BM, B210, BAD 310389. 


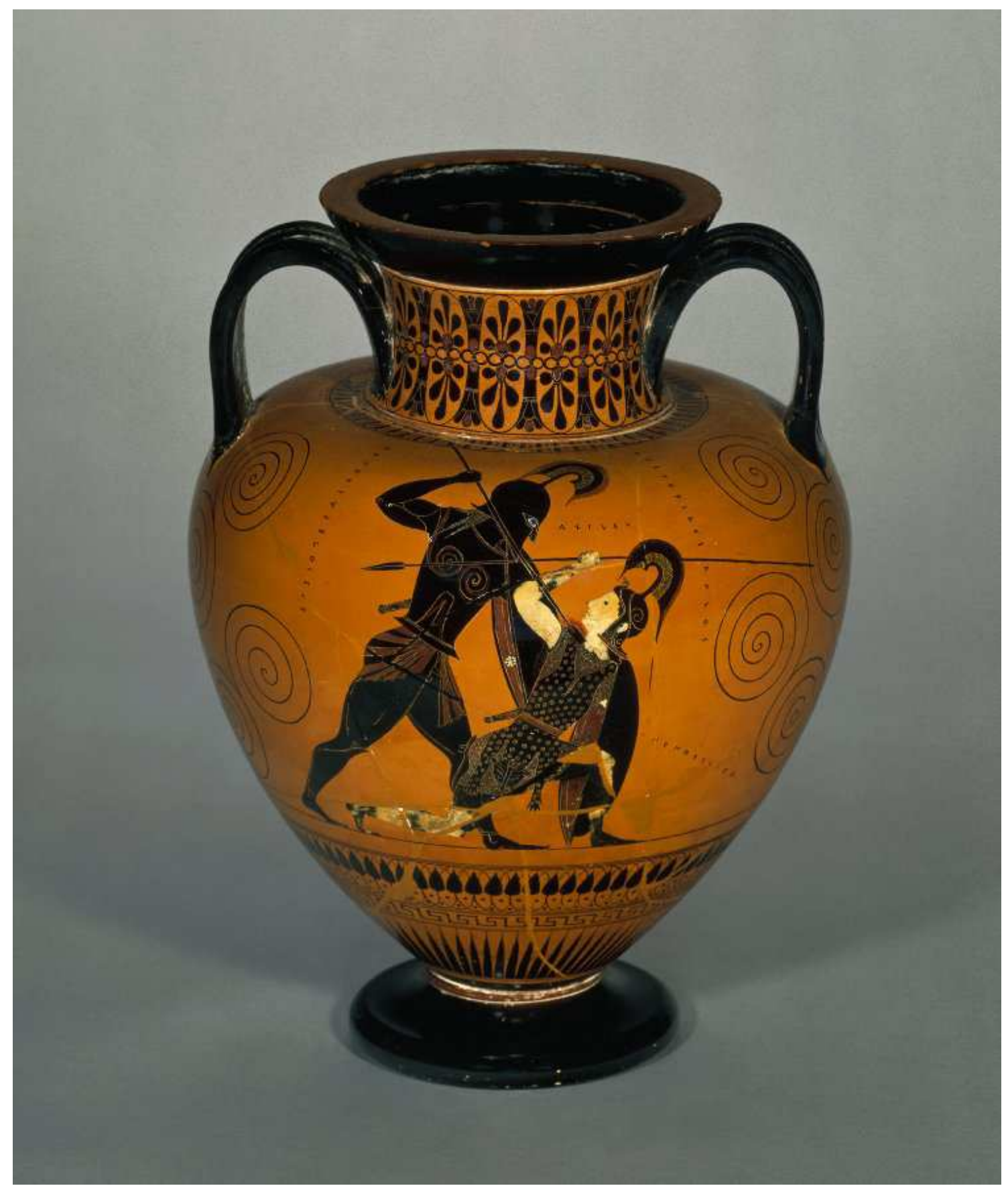

Fig. 5. EXEKIAS, Achilles and Penthesilea, Black-figure amphora, ca. $530 \mathrm{BC}-525 \mathrm{BC}$ London, British Museum B210 (Photo: (C) The Trustees of the British Museum)

All the features are evident in a number of archaic examples and it is best shown in the beautiful Archaic red figure tondo of the cup in Berlin ${ }^{44}$ (Fig. 6). Thus, adopting the same approach, in the scene of the Agora dinos (Fig. 3) we cannot see the Nymph's escape as a snapshot of an escape and an attack, but as a collection of gestures of an ordinary love scuffle, seen as a confrontation which is solved with an encounter and is represented in a single complex image.

${ }^{44}$ Berlin, Antikensammlung, F2279, BAD 200977. 


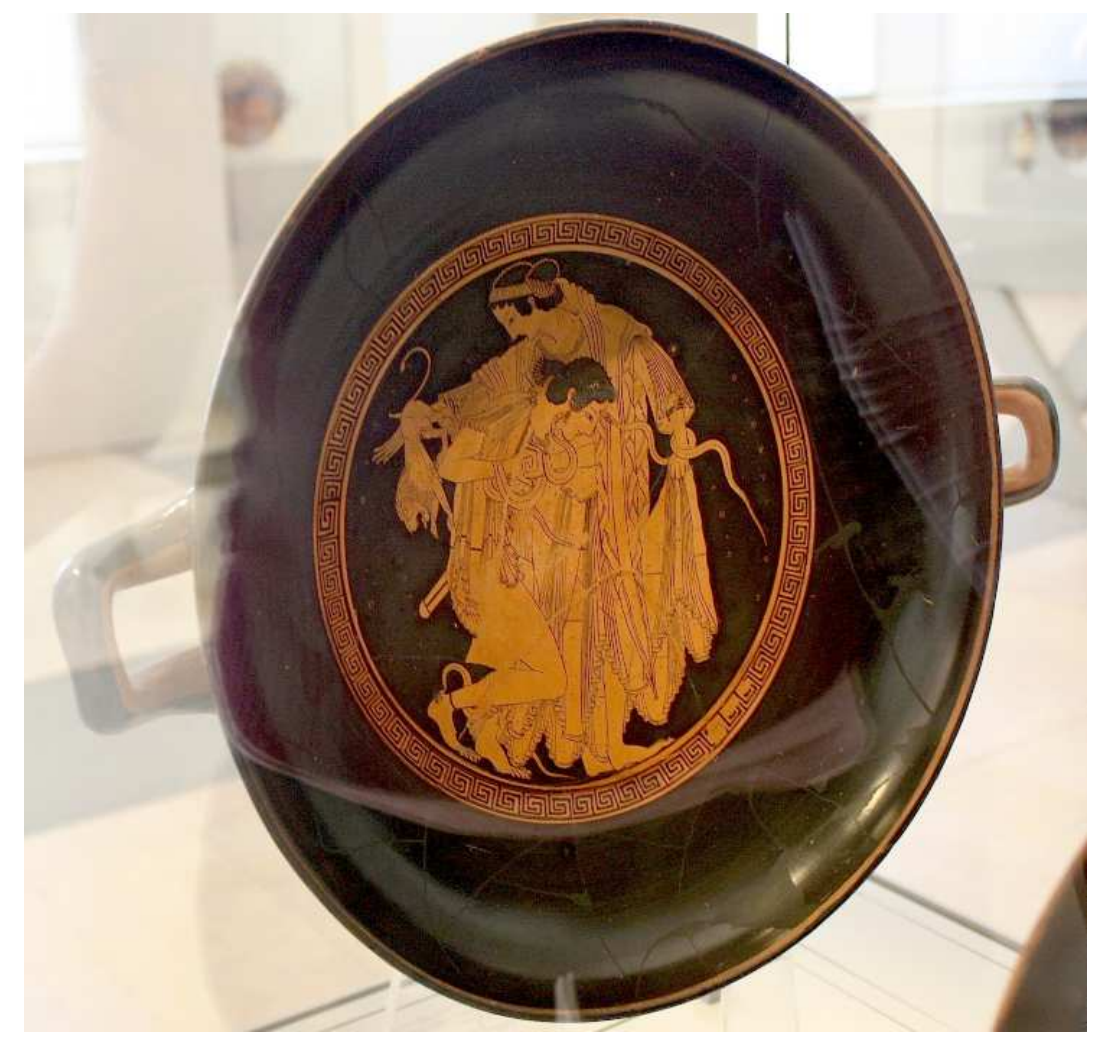

Fig. 6. PEITHINOS, Peleus and Thetis Tondo. Red-figure cup, ca. 500 BC Berlin, Antikensammlung, F2279, (Photo: Fátima Díez)

Nevertheless, the image of the Buffalo lekythos (Fig. 2) places us before a kind of rather strange love scene, in which the animal's participation introduces a new element which interferes in the couple; an unparalleled scene, as we have seen, which can be linked to the wild world and to hunting ${ }^{45}$ but which poses, however, equally interesting visual questions. On the one hand, the presence of a mule -or a big donkey - refers us to the world of Dionysus, whereas the scenes of the Return of Hephaistos introduce the role of the animal to carry Hephaestus, using, according to Isler-Kerenyi, an iconographical motif she identifies as "the horseman of the mule", an earlier Dionysiac figure, without a very convincing explanation ${ }^{46}$. On the other hand, the Silen's action over his cavalry, which he uses to attack the Nymph the mule or donkey is biting the woman-, causes a peculiar effect of identification between both, as if the Silen and the animal could be the same thing, that is, as if the Silen's identity could be exchanged with that of the mule, which is the one that actually catches the Nymph, as if an extension of his personality had taken place. Regarding the Nymph's reaction in front of this completely unusual attack, her attitude is similar to that in the earlier cases: it is evident that she is running away, making her skirt rise, but she turns to look at that who has already caught her and her attitude is not one of panic, pain or fear-emotions that are perfectly codified in Archaic figuration-, but her escape, once again, appears as a "funny" gesture -like the Silen's attitude and the animal's capriole — which fulfils an expected outcome.

\footnotetext{
${ }^{45}$ ISLER-KERENYI 2001: 82.

${ }^{46}$ ISLER-KERENYI 2001: 43-44, 90-97.
} 
A pursuit that is seen as a game, a kind of "tag" playing, in which she has to run away, but she knows the donkey-Silen is going to catch her, because those are the rules of the game. Finally, the scene visually evokes some interesting ideas. The composition, the Nymph's escape, the horse's capriole and the Silen's size regarding his cavalry remind us of the scenes of Achilles lying in wait for Troilus -like the one on the François vase (Fig. 7). Kleitias' version of the episode has the elements of an erotic pursuit that affects the ephebe, but which shows Polyxena running away scared, although she is not actually the real erotic aim, but happens to be involved in Troilus' escape and affected by the threatening cavalry ${ }^{47}$.

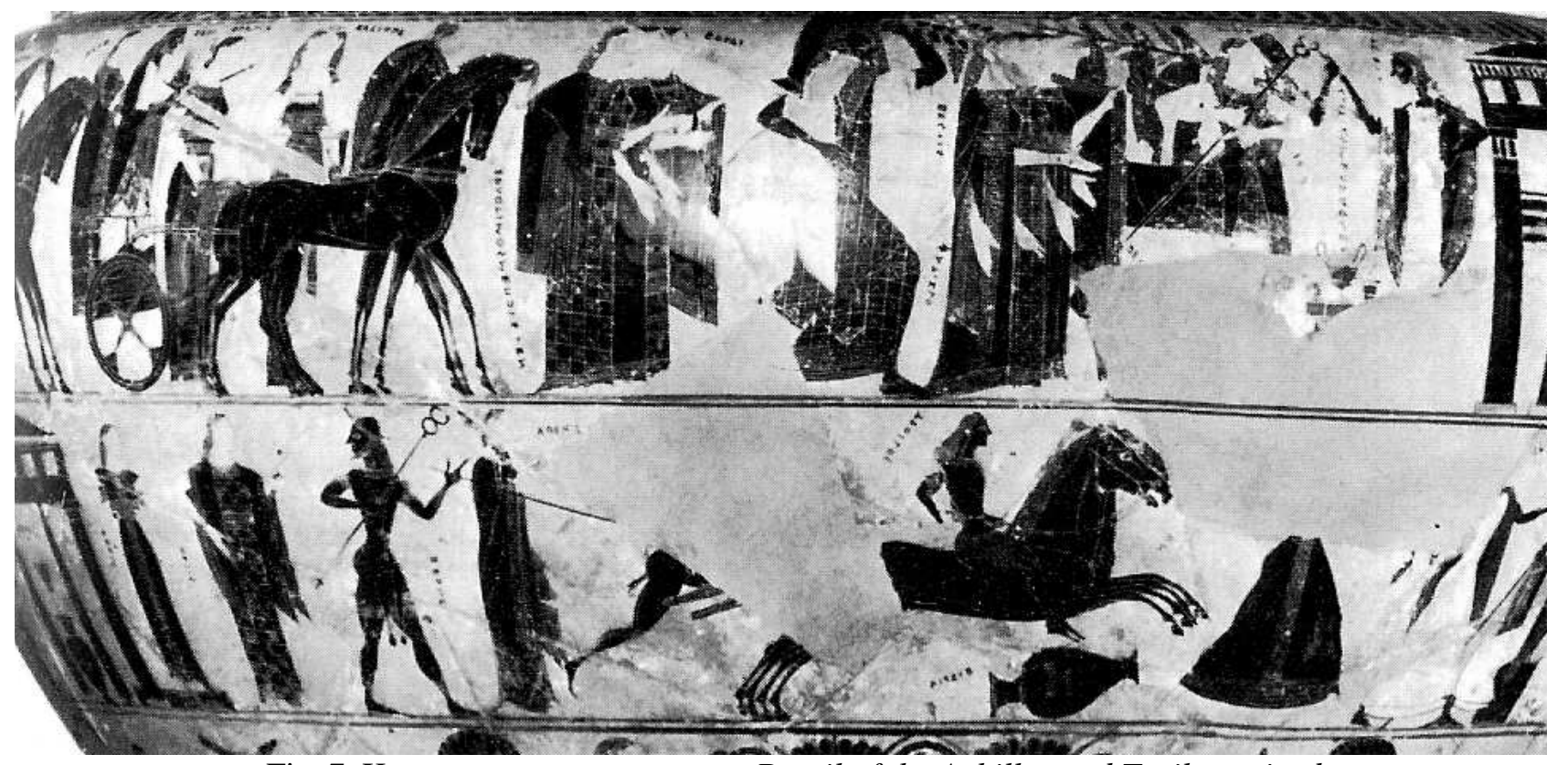

Fig. 7. KLEITIAS AND ERGOTIMOS, Detail of the Achilles and Troilos episode François crater, 565 BC. Florence, Museo Archeologico,4209.

(Photo: BOARDMAN 1974: fig. 46.5)

The visual concomitances and the shape of the vase, a lekythos that, in principle, is not a recipient intended for the banquet, give the group some special characteristics. Taking the capacity of inversion of reality into account, perhaps the image of the Silens and Nymphs, who are themselves an inversion of the human reality of sexes and show a wild version of the relationships between them, on scenes like this on the Buffalo lekythos, which seem to narrate an unknown episode, could be interpreted as the inversion of well-known epic episodes, alluded by using recognizable visual elements. If we change the actors of the scene and, especially, substitute them for the Silens and Nymphs, we turn a heroic scene, paradigmatic in one aspect or another, into a scene which is not necessarily only comic, but placed in a new setting which brings it closer to man thanks to transgression, that is, takes it to the limit, to those intermediate limits where Dionysus' companions live. In this way, the version of the lekythos both evokes and betrays the nature of the scene of Polyxena, but it brings about a new interpretation using well-known references for other purposes: exciting, arousing, reminding or celebrating desire. The vase where the scene is found, which could be

${ }^{47}$ ISLER-KERENYI 2001: 91. 
a table vase, perhaps a feminine one, with a clear feminine protagonist, refers to an episode in which the role of the woman, the fountain and the vessel-elements related to the world of women - are very relevant, but in which the feminine role has also changed, and the "Polyxena" of the inverted world escapes - only apparently - from a hostility which is also only apparent, which does not turn against her, but involves her in a desired game.

Similarly -and always from the visual point of view- I would like to explore the possibility that the first scenes of the two dinos -which I have talked about at the beginning of this section, and which represent the starting point of the scenes of pursuit and coercion between Silens and Nymphs- could also be seen as exercises of inversion of paradigmatic scenes of pursuit, fight or kidnapping. A few lines above we have already pointed out that the condensation of the erotic relationship between Silens and Nymphs in a bifrontal image of rejection-escape/acceptance refers, in the way it develops, to the images of a paradigmatic fight, like the one of Peleus with Thetis, well-known and very popular in the pottery of the same period. The problem that arises is the fact that this formal relationship may be conditioned by meaning, that is, whether the fight shown in a similar way, responds to a relation of meaning which tries to present the love confrontation between Silens and Nymphs like the one between Thetis and Peleus, with the ingredients of the relationship between sexes and the agonistic sense that this last episode entails.

Ingomar Weiler, in his book about agon in myths, classifies the different competitions according to the reasons that cause them, establishing the category of "wedding agons" 48 , that is, the fights or competitions which take place in mythology due to a wedding reason. Previously, in the list of athletic agons, he already includes two of those fights caused by the conquest of a bride: the stories of Thetis and Peleus, and Hippomenes and Atalante. Both episodes share the same odd characteristic: the bride is a prize and adversary at the same time, and therefore, although Weiler does not mention it in a special way, they are exceptional agons, which highlight two important aspects: on the one hand, they describe the action of the woman's submission using the idea of a fight which ends up in the male's victory $^{49}$; on the other hand, they give the woman at first the status of active subject, who stands on equal terms (or with an advantage, if we pay attention to what the myth says) with her potential partner, causing a real confrontation between sexes; the defeat will be for the female, but not without fight.

In a special way, the agon of Thetis y Peleus shows, besides love and the desire for a wife incarnated by Peleus obeying an order of the gods, a series of interesting aspects as a paradigm of a nuptial scene ${ }^{50}$. In the first place, the submission of a

\footnotetext{
${ }^{48}$ I. WEILER, Der Agon im Mythos, W. B., Darmstadt, 1974, pp. 256-258.

${ }^{49}$ On the consideration of marriage as man's victory over the wild condition of the bride, who is seen as a kind of animal that must be tamed, there is plenty of bibliography that highlights the different aspects of this comparison: CALAME 2002: 2002 as regards the sources and the religious aspect, and C. SOURVINOU-INWOOD, "A Series of Erotic pursuits: Images and Meanings", in JHS, 107, 1987, p. 131-153, and J. H. OAKLEY-R. H., SINOS, The Wedding in Ancient Athens, The University of Wisconsin Press, 1993 regarding the wedding and its aspects.

${ }^{50}$ See SourvinOU-InwoOd 1987 for the analysis of the relationship between both, Thetis and Peleus and Hippomenes and Atalante as models of erotic pursuit, developing the wedding aspects and analysing some of the inversions which take place, always bearing in mind the
} 
savage girl, a sea Nymph, who due to her special relationship with water is gifted with an exceptional capacity for metamorphosis, almost a lethal weapon that will be defeated by perseverance, love or ruse (depending on versions); in the second place, a real fight with a strong violent component, and, finally, a heroically happy ending, which we do not see in the scenes of fight, but we do know beforehand: Achilles.

The athletic agon of Hippomenes and Atalante involves less violence in the development, but not in the possible outcome: the defeated suitor's death. But the race virtually turns into pursuit: Hippomenes' race is to win and save his life, but at the same time it is to win Atalante for his bride, which is his aim, and Atalante's is to literally escape from Aphrodite's gifts -this is how it is expressed in Hesiod's passage (Fr. $76 \mathrm{M}-\mathrm{W}$ ) which reconstructs the story- and therefore from the male, represented in that moment by Hippomenes himself. The result is the suitor's victory, who achieves his purposes, that is, his life and the bride, while Atalante must submit to the male, accepting Aphrodite's gifts, which she picks up in the shape of an apple. On the other hand, regarding the identity of the contenders, there are certain concomitances with the case before: Hippomenes -like Peleus - is a hero helped by the gods; Atalante is a wild maiden raised in the mountains and so she has a special relationship with nature, like Thetis. The nuptial sense of the episode is obvious and it emphasizes the girl's rough or wild nature, which the textual sources remind us about.

The agonistic character, along with the brides' identity in both episodes, could be considered an element that is favourable for establishing a kind of comparison between this "fight between sexes" and the one between Silens and Nymphs, which would appear as an inverted image of a wedding story. The result would be the presentation of these wedding competitions expressed in a "Dionysiac language", some kind of agon countermodels: something similar to the "parody" of the conquest of a difficult wife in a heroic way ${ }^{52}$.

This inverted formulation undoubtedly takes place in figuration, where the proximity of the iconographical models has been seen quite often, suggesting a relation between the different ways Silens attack Nymphs in Ancient pottery and the repeated scenes of pursuit or struggle between Thetis and Peleus, which are clearly popular in Archaic figuration, especially in vascular painting ${ }^{53}$. The LIMC

problem of the taming of the girl. In this study, Thetis is regarded as a paradigm of "wild" girl and her metamorphosis as an image of this lack of domestication -an aspect I do not quite agree with- and the story of Atalante as an inversion in itself (SOURVINOU-INWOOD 1987: 138, $145-146$ and 152-153).

51 I do not really like the "parody" expression because I do not think it is only a comic or burlesque question underlying.

52 LISSARRAGUE suggests that the images of Silens who emulate heroes -commenting on a scene which is probably wrongly interpreted - might be simple parody exercises (LISSARRAGUE 1990a, pages 232-236)

53 The development of the love relationship between Thetis and Peleus takes place in several stages: lying in wait, pursuit, attack and fight (R. VOLLKOMMER, s.v. Peleus LIMC VII, p. 269) The first three stages are not often represented, but the fight consists of 350 scenes in attic pottery, from 520 to $460 \mathrm{BC}$. In the mentioned reference we find the specific bibliography of the iconographical topic, to which we must add Barringer's study on the image of the Nereids (J., BARRINGER, Divine Escorts. Nereids in Archaic and Classical Greek Art, The University of Michigan Press, 1995), which Vollkommer does not mention. BARRINGER devotes a few pages 
reference about Peleus recalls this relation in the iconographical commentary of the images when, after pointing out that in four illustrations of the episode Peleus is wearing a feline skin over a short chiton, it is stated that "this may allude to the love fights between Satyrs and Maenads"

On the other hand, a couple of fragmentary scenes on some bronze Argive belt bands of the Archaic period ${ }^{55}$, containing the wrongly interpreted representations of what seems to be a naked man's pursuit of a woman, placed on both sides of a tree and what seems to be a burning altar (Fig. 8), have been interpreted as an image of Thetis and Peleus - always because of the presence of the altar - in a version which is previous to the fight and the metamorphosis, the one which is depicted as the lying-in-wait phase. Clearly, Peleus' attitude, with his knees bent, in accordance with Archaic conventions, could be trying to indicate both a pursuit (knielauf scheme), and a scene of lying in wait behind the tree ${ }^{56}$, which is how the image of the hero's fight for the Nereid can be identified; on the other hand, the supposed figure of Thetis is extremely expressive, she turns towards her pursuer as she appears with the lower part of her peplos opened, showing her leg -as we can see Thetis and her sisters in other archaic scenes ${ }^{57}$ and like many of the dancing or chased Nymphs in several scenes in ancient pottery--, a gesture which can be interpreted as a sign of race or of seduction (or perhaps as both), and, moreover, she's holding what seems to be a stone in her raised right hand, like the Nymph on the Agora dinos (Fig. 3) ${ }^{58}$.

to the iconographical and meaningful relation of the representations of Thetis and Peleus' fight with the Dionysiac scenes, pointing our that MCNALLY 1978, SCHÖNE 1987 had already noticed that the images of Peleus seizing Thetis and holding her tightly have counterparts in the scenes of Silens attacking the Nymphs, showing exactly the same position, offering moreover the iconographical analysis of different vases where mixtures, allusions and loans are evident (BARRINGER 1995: 78, n. 39 and 80-82).

54 A very badly analyzed Attic black figure lekythos of the Keramaikos shows a scene of a couple beside an altar, which is doubtfully read as "satyr and Maenad beside an altar (Peleus and Thetis?)" (BAD 350, with bib.).

55 They both show a similar scene, described as "a young, naked man, identified as Peleus, a tree, a burning altar and Thetis", without making subsequent commentaries on the iconographical elements which appear in the scene (VOLLKOMMER, s.v.Peleus LIMC VII, numbers 49 and 50 with bib.)

56 The scene of ambushing, reduced to a couple, reminds us of a scene on a Chalcidicean vase in which a Silen is spying or lying in wait for a Nymph who seems to be running away or dancing.

${ }^{57}$ BARRINGUER 1995: 80-81.

${ }^{58}$ However, these argive scenes of lying in wait could be interpreted in different ways, even as regards the episode of the Garden of the Hesperides, showing the different possibilities of iconographical loans which the fixing of the image of the mythical tales in the archaic period brings about. The identification is done by comparison with a Corinthian vase which shows a scene of lying in wait where the character is clearly identified as Peleus with an inscription (Louvre E 639; LIM VII, s.v. Peleus, n 47 with bibliography), although the elements are not the same in both scenes (BARRINGUER 1995: 80-81). 


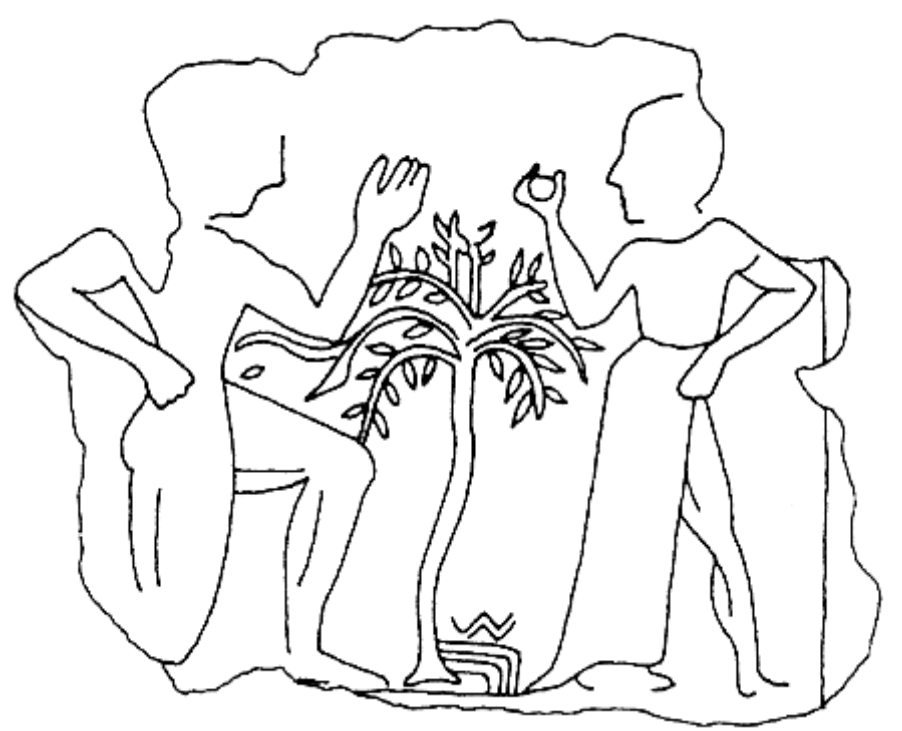

Fig. 8. Bronze belt band (Drawing). Archaic period. Argos Museum.

(Photo: LIMC VII, P. 255)

The pretended stone is the controversial point of the image, for if it is a stone, as it can be regarded in the case of Thetis' defence, it becomes a sign of aggressiveness and introduces at the same time a rural element, a natural weapon, which has been considered a symbol of the uncivilized behaviour of Centaurs and Silens, who indeed appear in violent scenes throwing stones ${ }^{59}$; but on these scenes, and especially on the one of the Agora dinos, lust seems to be the centre of attention. The Nymph on the Athenian vase undoubtedly seems to indicate that one of the intentions or stages of the compressed episode is the throwing of the object in her hand, but the hypothesis of the stone is extremely naturalistic, whereas the hypothesis that it may be a piece of fruit, such as an apple, instead of a stone, opens new possibilities which increase the erotic sense of the scene. The expression "throwing apples" in Greek has a clear erotic meaning, confirmed by Hesiquius ${ }^{60}$, besides referring to different episodes which involve the competition or the obtaining of an apple, from the judgement of Paris to the episode about Hippomenes and Atalante's race.

The commented scenes refer in their elements to the wedding agons we commented above as if the iconographical approach we see between the scenes could be due to the proximity of meanings which can be seen between both heroic episodes of the conquest of a bride. We must also mention that there are practically no Archaic representations of the episode of Hippomenes and Atalante, despite having access to such an expressive source as Hesiod's tale, which perfectly describes the characteristics of the athletic confrontation, as we have seen. Thus, we might be in front to some kind of vacillation phenomena in the fixing of the image, or some kind of motif contamination; analysing them from this point of view could perhaps provide a small figurative apparatus to the episode of the race in the Archaic period.

\footnotetext{
${ }^{59}$ LISSARRAGUE 1993.

${ }^{60}$ Hsch. s. v. méloi baleîn (M 1202 Latte). For apples and quinces and their erotic sense, see CALAME 2002: 166.
} 
As regards the scene of the dinos and the possibilities of relating it with a nonheroic version of the episode of Hippomenes and Atalante, there is still a very interesting element, offered by the interpretation of the vase as a whole, which is made up of several bands decorated with different scenes. In the upper part we see a festive scene of exaltation of wine - a komos - with dancers and the representation of the vases of the mixture of wine and water; the lower stripe, however, shows, as commented above, two mythological scenes with a certain agonistic touch: the hunting of the Calydon wild boar, with all the participants identified by their inscribed names -Peleus and Atalante among them ${ }^{61}$ - , and the funeral games in honour of Pelias; between these two scenes is where we find the "love" scene between the Silen and the Nymph. The heroic scenes cause a strange effect in relationship with the erotic scene, as if a kind of confrontation were taking place, which supports the hypothesis about the game of inversion, or perhaps about a game of transition to the other side of the mirror, presenting a version of the scenes of conquest of the wife by using the fight or the race, with apples involved, but using something like a "Dionysiac code".

Thus, these initial scenes of the relationship between Silens and Nymphs seem to be extraordinary from different points of view. First of all, because they come from the realm of the Dionysiac circle and therefore they can freely express the erotic link, which forms the basis of the relationship between its members; but, moreover, because they visually seem to suggest models and stories or intentions, which the development of the collective image of the circle of the god and the codification of the gestures of harassment, courtship or sexual interaction will modify, drawing our attention to Dionysus' powerful influence. However, primary eroticism and the perception of the inversion of the heroic world will persist in the images, which will have to be analysed in order to continue looking for signs of relationships with specific scenes ${ }^{62}$.

\section{Epilogue: sex in the world of Dionysus}

"The heroic and aristocratic tone of this scene clearly contrasts with the one on the reverse, where the Dionysian thiasos succumbs to the parousia, to the game and to sexual excesses. The transition takes place in the images under the handles, the bordering space of the eschatia.

\footnotetext{
61 Peleus and Atalante's participation in both episodes, in the hunting of Calydon and in the funeral games in honour of Pelias in which, according to Apollodorus (3.106), the hero is engaged in a fight with the girl and is defeated by her, is one more element to find some kind of coherence in the interpretation of the vase which would include two heroic scenes and a "satyrical" one, with the same or similar characters who belong to the same environment.

${ }^{62}$ For the possiblity of linking the scenes of Silens and Nymphs to the nuptial world we need to mention E. KEULS' remarks in her famous book about sexuality in Athens, in a section she entitles "The Matrimonial Side of Maenadic Sex rituals" (E. C. KEULS, The Reign of the Phallus. Sexual Politics in Ancient Athens. University of California Press, 1993 (1st edition Harper and Row, New York 1985, p. 371-379), within the general chapter on the antagonism of sexes ("Sex Antagonism"), where she develops a few interesting ideas about the opposition and reconciliation of sexes. However, from the visual point of view, she focuses her attention mainly on the red figure scenes, better known and more numerous, belonging to a decisive period for Athens, which is the 5th century BC.
} 
Monsters and wild beasts live in this territory of alterity: (...) The liminality of satyrs is expressed in their appearance and actions (...) It is only in this parallel universe, where everything is possible and human norms are inverted, where these intermediate beings, wild and bordering, can act. The wine and music of the Dionysiac party, and the satyrs' inexhaustible sexual energy, have unleashed the transgression, the inversion of the heroic model which the scene in the front celebrated, and the metamorphosis of those who can see themselves in this double mirror of the images which lead the meeting around wine". ${ }^{63}$

With this beautiful commentary of a crater from the circle of Lydos ${ }^{64}$ showing a scene of Achilles receiving the weapons from Thetis and a scene of the Dionysiac circle, P. Cabrera perfectly describes the peculiarities of the image of the Dionysiac world, and especially, - I would like to add - of the human counterpoint represented by the Silens and Nymphs as regards the erotic relationship I have been discussing throughout these pages.

The contemplation of these inverted models in action, and especially, in the erotic action, on the surfaces of the vases of the symposium seem to turn into an invitation to transgression, to step to "the other side of the mirror", where we find the world of the relationships favoured by wine and by the contact with the god and his gifts, an escape to a territory which is outside the polis, but which you can reach from its very centre, because it is inside each and every one of us, in the member of the audience and the wine drinker. A place "where everything is possible", the desired territory of illusion, imagination and the true "virtual image": the world of Dionysus.

\section{Bibliography}

BARRINGER, J., Divine Escorts. Nereids in Archaic and Classical Greek Art, The University of Michigan Press, 1995.

BERARD, C.-BRON, CH., "Satiric Revels" in C. BERARD ET AL. (eds.), A City of Images. Iconography and Society in Ancient Greece, Princeton, New Jersey, 1989, p. 131-150.

BERMEJO BARRERA, J. C.- DÍEZ PLATAS, F., Lecturas del mito griego, Akal, Madrid, 2002.

BIEBER, M., "Two attic black-figured lekythoi in Buffalo" in AJA, 1944, 121-131.

BOARDMAN, J. Athenian Black-Figure Vases, London, 1974.

BUXTON, R., Imaginary Greece. The contexts of mythology, Cambridge 1994

(Spanish translation: El imaginario griego. Los contextos de la mitología, Cambridge University Press, Madrid, 1994).

CABRERA BONET, P. (ed.), La colección Várez Fisa en el Museo Arqueológico

Nacional, Ministerio de Educación, Cultura y Deporte, Madrid, 2004.

\footnotetext{
${ }^{63}$ CABRERA BONET (ed.), La colección Várez Fisa en el Museo Arqueológico Nacional, Ministerio de Educación, Cultura y Deporte, Madrid, 2004.

${ }^{64}$ Madrid, Museo Arqueológico Nacional, colección Várez Fisa n. 50.
} 
CALAME, C., Eros en la Antigua Grecia, Akal, Madrid, 2002 (Spanish translation of L'Éros dans la Grèce Antique, Laterza, Roma-Bari, 1992)

CARPENTER, T. H., Dionysian Imagery in Archaic Greek Art: Its Developement in Black-figure Vase Painting, Oxford, 1986.

CHRISTOPULU-MORTOJA, E., Darstellugen des Dionysos in der schwarzfigurigen Vasenmalerei, Berlin, 1964.

DÍEZ DE VELASCO, F., "Iconografía de lo erótico en el mundo griego antiguo: de lo divino a lo físico (y viceversa) in Revista del Museo de Bellas Artes de la Coruña I, 2003,

DÍEZ PLATAS, F., "Las representaciones de las Ninfas en la cerámica griega arcaica y algunas consideraciones iconográficas", GALLAECIA. 17, 1998, p. 303-343.

DÍEZ PLATAS, F., "Los epítetos del amor y el deseo en la épica griega arcaica" in Actas del X Congreso Español de Estudios Clásicos, vol. I, Madrid, 2000, p. 385-390.

DÍEZ PLATAS, F., "Naturaleza y femineidad: los epítetos de las Ninfas en la épica griega arcaica", Cuadernos de filología clásica: estudios griegos e indoeuropeos, 10, 2000, pp. 19-38.

DÍEZ PLATAS, F., "Imaginando el agua: Reflexiones acerca del significado iconográfico de la serpiente en algunas escenas de la cerámica griega arcaica", in P. LÓPEZ BARJA -S. REBOREDA MORILlO (eds.), Fronteras e identidad en el mundo griego antiguo. Universidad de Santiago/Universidad de Vigo, Santiago de Compostela, 2001, p. 281-301

DÍEZ PLATAS, F., Las Ninfas en la literatura y en el arte de la Grecia arcaica. Universidad Complutense de Madrid. Doctoral dissertation CD-ROM, 2002.

DÍEZ PLATAS, F., "Dos caras de una cílica: sobre la iconografía de la copa de Fineo" GALLAECIA, 22, 2003, p. 87-102.

DURAND, J-L.- FRONTISI-DUCROUX, F.- LISSARRAGUE, F., "Wine: human and divine" in C. BERARD ET AL. (eds.), A City of Images. Iconography and Society in Ancient Greece, Princeton, New Jersey, 1989, p. 121-129.

EDWARDS, M. W., "Representations of Maenads on Archaic Red-figured Vases", JHS, LXXX, 1960, p. 79-87.

FRONTISI-DUCROUX, F, "Eros, Desire and the Gaze" in N. B. KAMPEN (ed.), Sexuality in Ancient Art, Cambridge University Press, 1996, p. 81-100.

HALPERIN, D. H.-WINCKLER, J. J.-ZEITLIN, F. I., Before Sexuality: The construction of Erotic Experience in the Ancient Greek World, Princeton, 1990.

HEDREEN, G., Silens in Attic Black-figure Vase-painting: Myth and Performance, Ann Arbor, The University of Michigan Press, 1992.

HEDREEN, G., "Silens, Nymphs, and Maenads", Journal of Hellenic Studies, vol. 114, 1994, p. 47-69.

HENRICHS, A., "Myth Visualized: Dionysos and His Circle in Sixth-Century Attic Vase-Painting", in Papers on the Amasis Painter and His World, Malibu,1987, p. 92-124.

HIMMELMANN, N., Erzählung und Figur in der archaischen Kunst, Wiesbaden, 1967

HOUSER, C., Dionysos and His Circle. Ancient through modern, Harvard University, Cambridge, 1979. 
KEULS, E. C., The Reign of the Phallus. Sexual Politics in Ancient Athens. University of California Press, 1993 ( $1^{\text {st }}$ edition Harper and Row, New York 1985)

KOSSATZ-DEISSMAN, A., "Satyr- und Mänadennamen auf Vasenbildern des GettyMuseums und der Sammlung Cahn (Basel), mit Addenda zu Charlotte Fränkel Satyr- und Bakchennamen auf Vasenbildern (Halle, 1912)", in Occasional Papers on Antiquities, 7, Malibu, 1991.

ISLER-KERENYI, C., Dionysos nella Grecia arcaica. Il contributo delle immagini, Istituti editoriali e poligrafici internazionali, Pisa-Roma, 2001.

LARSON, J., Greek Nymphs. Myth, Cult, Lore, Oxford University Press, 2001.

LISSARRAGUE, F., "Why Satyrs are Good to Represent" in J. J. WINCKLER-F. I. ZEITLIN (eds.) Nothing to do with Dionysos?, Princeton, 1990.

LISSARRAGUE, F., "The Sexual Life of Satyrs" in D. H. HALPERIN.-J. J. WINCKLER-F. I. ZEITLIN, (eds), Before Sexuality: The construction of Erotic Experience in the Ancient Greek World, Princeton, 1990.

Lissarrague, F., "On the Wildness of Satyrs" in T. H. CARPENTER AND CHR. A. FARAONE (eds.), Mask of Dionysos, Cornell University Press, New York, 1993, pp. 207-220.

MCNAlly, S., (1978) "The Maenad in Early Greek Art" in J. PERAdOTTO-J. P. Sullivan (eds.), Women in the Ancient World. The Arethusa papers 11, SUNYP, Albany, 1978, p. 101-135.

MORAW, S., Die Mänade in der attischen Vasenmalerei des 6. und 5. Jahrhunderts v. Chr. Receptionsästhetische Analyse eines antiken Weiblichkeitsentwurfs, Verlag Philipp von Zabern, Mainz, 1998.

OAKLEY, J. H.- SINOS, R. H., The Wedding in Ancient Athens, The University of Wisconsin Press, 1993.

SCHÖNE, A., Der Thiasos: Eine ikonographische Untersuchung über das Gefolge des Dionysos in der attischen Vasenmalerei des 6. und 5. Jhs. v. Chr., Goteburgo, 1987.

SHAPIRO, H. A., Myth into Art. Poet and Painter in Classical Greece, London, 1994 SNODGRASS, A., An Archaeology of Greece, Barcelona, 1990.

SNODGRASS, A., Homer and the Artists. Text and Picture in Early Greek Art, Cambridge, 1998.

SOURVINOU-INWOOD, CHR., "A Series of Erotic pursuits: Images and Meanings", in JHS, 107, 1987, p. 131-153.

VILLANUEVA-PUIG, M. C., "Les representations des Menades dans la ceramique attique a figures rouges de la fin de l'archaisme", REA, 94, 1-2, 1992, p. 125-154 VOLKOMMER, R., s.v. Peleus in LIMC VII.

WEILER, I., Der Agon im Mythos, W. B., Darmstadt, 1974.

YOUNG, R. S., “A Black-Figured Deinos” in Hesperia, 4, 1935, p. 430-441. 